University of Wollongong

Research Online

Faculty of Business - Papers (Archive)

Faculty of Business and Law

$1-1-2016$

\title{
Ethnic diversity and trust: new evidence from Australian data
}

Silvia Mendolia

University of Wollongong, smendoli@uow.edu.au

Alex Tosh

University of Wollongong

Oleg Yerokhin

University of Wollongong, oleg@uow.edu.au

Follow this and additional works at: https://ro.uow.edu.au/buspapers

Part of the Business Commons

Research Online is the open access institutional repository for the University of Wollongong. For further information contact the UOW Library: research-pubs@uow.edu.au 


\title{
Ethnic diversity and trust: new evidence from Australian data
}

\author{
Abstract \\ This paper investigates the relationship between neighbourhood ethnic and linguistic heterogeneity and \\ individuals' local and generalised trust. A wide literature across economics and sociology has recognised \\ the importance of trust in facilitating economic growth and development. We use fixed effects and \\ instrumental variable regression and control for a wide set of individual and local area characteristics. Our \\ results show that a 1 standard deviation increase in ethnic and linguistic fractionalisation is associated \\ with a decrease in local trust of about 0.12 standard deviations, while we do not find any significant \\ relationship between heterogeneity and generalised trust.

\section{Disciplines} \\ Business \\ Publication Details \\ Mendolia, S., Tosh, A. \& Yerokhin, O. (2016). Ethnic diversity and trust: new evidence from Australian data. \\ The Economic Record, 92 (299), 648-665.
}




\title{
Ethnic diversity and trust: new evidence from Australian data
}

\begin{abstract}
This paper investigates the relationship between neighbourhood ethnic and linguistic heterogeneity and individual's local and generalized trust. A wide literature across economics and sociology has recognised the importance of trust in facilitating economic growth and development. We use fixed effects and instrumental variable regression and control for a wide set of individual and local area characteristics. Our results show that a 1 standard deviation increase in ethnic and linguistic fractionalisation is associated with a decrease in local trust of about $12 \%$ of a standard deviation, while we do not find any significant relationship between heterogeneity and generalized trust.
\end{abstract}




\section{Introduction}

Successful functioning of modern society is predicated on the existence of a high degree of interpersonal trust among its members. When individuals trust one another they are more inclined to cooperate and engage in mutually beneficial exchanges, leading to higher levels of economic development (Arrow, 1972). Cross-country comparisons suggest a strong positive link between trust and economic growth rate (Knack and Keefer, 1997), per capita income (Algan and Cahuc, 2010, 2013) and absence of excessive government regulation (Aghion et al 2010, 2011). At a more aggregate level, absence of trust between groups of agents is considered to be one of the primary causes of the costly and persistent inter-group conflicts that punctuate human history (Acemoglu and Wolitzky, 2014).

Existing empirical evidence suggests that one of the important determinants of an individual's trust towards other people is the level of ethnic heterogeneity of a community, city or country of residence. People living in racially or ethnically mixed areas tend to exhibit lower levels of trust compared to those residing in ethnically homogeneous communities. This was found to be true for generalized trust (Alesina and La Ferrara, 2002; Delhey and Newton, 2005), as well as inter-ethnic trust (Putnam, 2007). The literature has also documented a negative impact of ethnic and linguistic diversity on various measures of social capital, at the country level. (Wang and Steiner, 2015). If true, the negative relationship between heterogeneity and social capital has important implications for immigration and settlement policies in many countries that experience large inflows of migrants. Even though studies from various disciplines have provided evidence showing that the economic and social benefits of immigration are remarkable (see for example Johnson, 1994; Muysken and Ziesemer, 2013; Zelekha, 2013; Fratzscher and Junker, 2015; Ng and 
Metz, 2015), it is important to consider all possible channels through which immigration impacts society. Understanding the full extent of the effect of ethnic heterogeneity on trust (and social capital in general) is, therefore, vital for formulating a well-designed immigration policy.

This issue is of particular importance for Australia, which, following the official adoption of a multicultural immigration policy, has implemented an expansive immigration program, welcoming migrants from many diverse backgrounds (OECD 2006). Since the immediate aftermath of the Second World War, the percentage of the Australian population born overseas has increased from approximately $9.8 \%$ in 1947 to approximately $27.7 \%$ at June 30 , 2013 (ABS 2013; Phillips, Klapdor \& Simon-Davies 2010). Furthermore, the vast majority of overseas born Australian residents in 1947 were born in countries that were ethnically or culturally very similar to Australia, with $78.6 \%$ of the overseas born population hailing from the United Kingdom, Ireland, or New Zealand. In 2011, this figure had fallen to approximately $28.9 \%$. Australia's ethnic diversity has thus increased not only as a result of a larger intake of migrants, but also as a result of a more diverse intake. Australian experience with immigration policy is unique and quite different from other countries, and notably Western European countries. As noted in Castles (1992), there are major differences between the migratory experience in Australia and Western Europe, in particular due to geographical factors and relative size of the immigrant population, as well as to the role of immigration policy based on the ideas of permanent settlement and nation-building in Australia.

This paper studies the relationship between generalized and local or neighborhood level trust and ethnic and linguistic heterogeneity in the Australian context. In contrast to the 
previous literature it uses a longitudinal household survey. This makes it possible to consider identification strategies, which were not used in this context previously. It also adds to the existing Australian literature on the topic (Bullen and Onyx, 1999; Leigh, 2006) by testing the robustness of the results to different identifying assumptions and considering a wider set of indicators measuring generalized trust as well as local trust or social capital at the neighbourhood level. Our main results largely confirm the earlier set of findings reported in Leigh (2006). We find that in the Australian context ethnic and linguistic heterogeneity affects negatively local but not generalized trust. This result is robust to the different identification assumptions and measures of trust that we use.

The rest of the paper is organised as follows. Section 2 reviews existing literature on trust and its relationship with ethnic heterogeneity. Section 3 describes the data used in the analysis. Section 4 describes the econometric methodology, Section 5 presents our results and Section 6 provides concluding remarks.

\section{Literature review}

Existing literature makes a distinction between two different concepts of trust. First, a person can feel varying degrees of trust towards the people that she is acquainted with. This notion of trust relies principally on the information available to the person based on the experience of interacting with people in her environment. The second notion of trust is related to trust towards people in general; a general belief in the moral qualities of a person one meets for the first time without necessarily possessing any prior information about them. Uslaner (2002) defines the first type of trust as strategic trust. This notion of trust involves rational calculation and risk assessment based on the available evidence and it 
corresponds closely to the concept of trust as envisioned by economic theorists (Dusgupta, 1988) and which is a subject of experimental literature in economics (Berg et al, 1995). The second concept of trust is defined by Uslaner (2002) as moralistic or generalized trust. It is this ethical dimension of the trust that is important in understanding civic engagement and social capital more generally.

Empirical literature (see for example Knack and Keefer, 1997) on generalized trust has used some form of trust question similar to the one found in the World Values Survey and the US General Social Survey: "Generally speaking, would you say that most people can be trusted or that you need to be very careful in dealing with people?" The structure of the question implies that it applies to people in general, and not those necessarily known to the respondent and thus seems to rule out any strategic considerations based on prior experience. Even though the question is widely used, some studies have argued that generalized trust questions might measure the individual's trustworthiness rather than their attitudes toward other people (Glaeser et al., 2000). This view has however been challenged by Fehr et al (2003), who have argued that Glaeser et al (2000) results were likely driven by the non-representativeness of their sample.

A separate strand of the empirical literature has studied a different kind of trust question, in which respondents are asked whether they trust people in their neighbourhood (Leigh, 2006; Sturgis et al, 2011; and Putnam, 2007). Current literature agrees that this type of "trust in neighbours" question captures attitudes that are quite different from the generalized trust questions discussed above (Uslaner 2002, Sturgis et al, 2011), and relates to the trust in people the respondents are familiar with (Sturgis and Smith, 2010). Overall, Sturgis et al (2011) conclude that the trust in neighbors question "appears to be a mix of trust in strangers and the more strategic, or 'thick' variety of trust in known others." Despite 
its more ambiguous interpretation, it seems that the "trust in neighbors" or "local trust" question, where available, can serve as a useful comparison point in the studies of the determinants of trust, capturing (at least partially) the notion of strategic trust as it is understood, in particular, in economics literature.

Of particular relevance to the current study is the work by Leigh (2006), which investigated the determinants of trust with emphasis on ethnic and linguistic heterogeneity using data from the 1997-98 Australian Community Survey. The questions used by Leigh (2006) were worded as follows: (i) “Generally speaking, you can't be too careful in dealing with most Australians", and (ii) "Generally speaking, you can't be too careful in dealing with people in my neighborhood". The first question differs from a typical generalized trust question as it explicitly mentions nationality. It is therefore best thought of as measuring the generalized trust prevalent among Australians in that time period. The second question is a typical trust in neighbors or local trust question similar to those used by Sturgis et al (2011). After instrumenting the ethnic heterogeneity of the neighborhood with ethnic heterogeneity of a larger region in which it is contained, Leigh (2006) found that neighborhood level ethnic and linguistic heterogeneity affects negatively only local or neighborhood level trust and not generalized trust among Australian residents.

A similar finding was reported later in Sturgis et al. (2001) who used British data and found that only local trust (which they contend corresponds to a large extent to the notion of strategic trust) is affected by the ethnic heterogeneity. These results are important because they provide evidence against the "hunkering down" hypothesis advanced by Putnam (2007) who has reported evidence of the community level ethnic heterogeneity having a negative impact on intra and inter-ethnic trust in the US. By considering simultaneously generalized and local or strategic trust, both Leigh (2006) and Sturgis et al (2011) 
demonstrate that the latter construct is affected by the ethnic heterogeneity, while the former isn't.

This paper builds upon the analysis of Leigh (2006) and extends it in several ways. It uses data coming from the 2006 and 2010 waves of the Household, Income and Labour Dynamics in Australia (HILDA) survey. The use of HILDA data enables us to analyse a more recent period during which Australia continued to experience large inflows of international migrants. More importantly, the longitudinal nature of the dataset allows us to control for individual fixed effects when estimating the effect of heterogeneity on trust and to compare these results to those obtained using cross-sectional methods such as OLS and IV. While the fixed effects model itself is not completely free from threats to internal validity in this context, we believe that comparison of the results obtained under different identifying assumptions provides an important robustness check that increases our confidence in these results. Finally, we take advantage of a richer set of questions available in HILDA that can, in our opinion, be interpreted as proxies for generalized and local trust, to test whether our results carry over to these alternative measures.

\section{Data}

This paper uses data from the Household, Income and Labour Dynamics of Australia (HILDA) survey. The survey is an unbalanced panel with annual waves tracking household income and labour force participation variables over time for a representative sample of the Australian population. Changes in household composition, and a top-up sample added in the eleventh wave, have increased the number of participants over time. In total, 19,914 individuals were included in the initial wave. As additional people joined the original households they were also included in the survey. An additional top-up sample of 2,153 
households was added to the 2011 wave. The 2011 wave included 29,489 individuals. We use information collected at wave 6 and 10 (corresponding to years 2006 and 2010) of the HILDA survey, as questions relating to local or neighbourhood trust are only asked in those waves. Further, data on the proportion of people from different ethnic groups living in each postal code are collected from the Australian Census and this restricts the investigation to those years in which the census takes place, or the years immediately before and after. Our final sample includes over 20,000 observations from both waves, after excluding all individuals missing information on one or more variables of interest.

\subsection{Outcomes}

Our measure of generalized trust is based on the question in which respondents are asked to nominate on a scale of $1-7$ (from Strongly Disagree to Strongly Agree) the extent to which they agree with the following statement: "Generally speaking, most people can be trusted". Note that in contrast to the Australian Community Survey question on generalized trust used in Leigh (2006), the question in HILDA does not refer explicitly to any nationality. One can argue that this is essentially the same question as the generalized trust question found in the World Value Survey (WVS) and the US General Social Survey (GSS), except that it omits the second part "or that you can't be too careful when dealing with others?" Another difference is that instead of the binary response option specified in the WVS and GSS, the format of the HILDA question allows for trust to be measured on a scale from 1 to 7, and the magnitude of the effect of certain individual and community characteristics can be more accurately ascertained. Despite these minor differences, we believe that, similar to the WVS and GSS questions, the HILDA question should be interpreted as corresponding to the concept of generalized trust in the sense of Uslaner (2002). 
Following Leigh (2006) and Sturgis et al (2011) we use a "trust in neighbours" question available in HILDA to measure the concept of local or strategic trust. The question is worded as follows: "People in this neighbourhood can be trusted" and the range of possible answers is represented on a 1-7 scale similarly to the generalized trust question.

We also make use of the additional questions available in HILDA to supplement our analysis related to the trust measures discussed above. It must be noted at the outset that these questions were not used in the context of the trust literature and that there exists a potential ambiguity as to the exact correspondence between them and the trust concepts discussed above. We use them primarily to enrich the analysis by investigating if these new variables respond to diversity in ways which are similar to the trust indicators. A reader who does not agree with our interpretation of these measures should feel free to draw their own conclusions from this subset of the results.

First, we use three additional questions which can be thought of capturing the belief in the moral qualities of other people with whom the respondent is not necessarily familiar, and therefore serve as alternative proxies for generalized trust. These questions ask the respondents about the extent they agree with the following statements:

1. "Most people would try to take advantage of you if they got a chance."

2. "Most people you meet keep their word."

3. "Most people you meet make agreements honestly."

It must be acknowledged that the wording of questions 2 and 3 might suggest that they refer to the people the respondent deals with on a day to day basis (be referring to the "people you meet" rather than people in general) and that these questions might be 
interpreted to some extent as measuring strategic or calculative trust (Williamson, 2003) rather than generalized trust. On the other hand, the empirical results show that specifications that use these measures as dependent variables produce similar results to the one where the main generalized trust question is used.

Second, we use three questions related to measures of the social cohesion of the neighbourhood in which a respondent resides to supplement the analysis of the local or strategic trust. This set of questions is a subset of the questions used by Sampson et al (1997) in their study of collective efficacy and neighbourhood level crime. The questions that we use in this analysis assess the extent to which an individual agrees to the following statements:

1. "This is a close-knit neighbourhood."

2. "People in this neighbourhood generally do not get along."

3. "People in this neighbourhood generally do not share the same values."

While these measures do not refer to local trust explicitly, they can serve as indirect indicators of how neighbourhood level diversity can affect community cohesion and local trust. For example, if living in an ethnically mixed neighbourhood has an impact on the respondent's belief that people in the area do not get along and do not share the same values, it is likely that she will exhibit less trust in dealings with her neighbours.

Table 1 reports sample mean values and standard deviations for the different measures of trust. Each of these values falls within a range of 1 to 7 . There is a consistent increase in levels of trust (or decrease in perception of untrustworthiness) between 2006 and 2010, though the magnitude is negligible in some cases. Generalized trust levels are higher than 
local trust levels. Respondents are more likely to report that they trust other individuals in their local area than they are to report that they get along with, or share the same values, with other individuals in their local area.

\section{Table 1 here}

\subsection{Ethnic diversity}

In our study, we use community characteristics data from the Australian Census of Population and Housing (the 'Census'). The Census is a survey conducted every five years, with the principal purpose of determining the number and characteristics of people and dwellings in Australia on census night. For every resident of every postcode there is a record of ethnicity based on country of birth and a record of ancestry based on country of parent's birth (ABS, 2006; 2011). An individual is considered to belong to an ancestral group where at least one of that individual's parents was born in that ancestral group's home country. For this reason, an individual can belong to two ancestral groups. The census similarly records a 'Language Spoken at Home' for every individual in every postcode. Following the literature, (Leigh 2006; Alesina and La Ferrara 2002) we construct Herfindahl indices of neighbourhood fractionalisation based on ethnicity, ancestry, and language spoken at home. These indices measure the probability that two randomly drawn individuals from the neighbourhood population will have different ethnicities, ancestral backgrounds, and language preferences respectively.

The indices are created according to the following formula:

Ethnic Fractionalisaion $=1-\sum_{e=1}^{N} S_{e j}^{2}$

Where $\mathrm{S}_{\mathrm{ej}}=$ Share of ethnic group $e$ in neighbourhood $j$ 
Linguistic Fractionalisation $=1-\sum_{l=1}^{N} S_{l j}^{2}$

Where $\mathrm{S}_{\mathrm{lj}}=$ Share of linguistic group / in neighbourhood $j$

Ancestral Fractionalisation $=1-\sum_{a=1}^{N} S_{a j}^{2}$

Where $\mathrm{S}_{\mathrm{aj}}=$ Share of ancestral group $a$ in neighbourhood $j$

In each case, a fractionalisation index score of 0 would indicate a completely homogeneous population, with no ethnic, linguistic or ancestral diversity. An index score of 1 would indicate a completely heterogeneous population where each individual member of the population belonged to a unique ethnic, linguistic or ancestral group.

Other measures of fractionalisation used in the literature include the measures proposed by La Porta et al (1999) and Desmet et al (2012). Desmet et al (2012) seek to explain the crosscountry differences in political and economic outcomes hypothesising that linguistic diversity between languages of a common ancestral origin is different in nature to linguistic diversity between languages from differing linguistic branches. The indices used in La Porta et al (1999) are more closely related to the ones used in the current study. They use the average value of five different indices in their analysis, some of which are, similarly to this study, Herfindahl type indices corresponding to the probability that two randomly selected individuals belong to the same ethnolinguistic group or speak the same language, and the others are proportions of populations that do not speak the official or most widely used language. Note however, that the latter indices measure the dominance of a given language and not diversity and would therefore not be suitable for the type of analysis undertaken in this paper. 
As expected, the three indices are very highly correlated. The indices for ethnic fractionalisation and ancestral fractionalisation have a correlation of 0.9566 . However the ethnic fractionalisation index has a distribution that more closely approximates a normal distribution. Ethnic fractionalisation will therefore be used rather than ancestral fractionalisation. Separate regressions will use the linguistic fractionalisation index to verify the robustness of our main results. Both ethnic and linguistic indices have potential limitations. The ethnic fractionalisation index may overstate the level of diversity by applying the same weight of difference to individuals from separate but very similar ethnicities (such as individuals from the USA and Canada) to individuals from more markedly different backgrounds (such as individuals from Egypt and China, for example). The index of linguistic fractionalisation may overcome this issue by effectively grouping similar ethnicities with common linguistic heritages. However, the linguistic fractionalisation index can be misleading insofar as it does not accurately reflect the average level of English proficiency in the neighbourhoods; it only reflects the language primarily spoken at home. Using both indices should provide the required robustness.

The average postcode level neighbourhood in Australia has a population of approximately 20,000 individuals. The probability of any two randomly selected individuals from the average Australian postcode level neighbourhood belonging to the same ethnic group is approximately $45 \%$. The mean values and standard deviations remain stable for the ethnic fractionalisation and ancestral fractionalisation indices between the 2006 and 2010 samples, however the average level of linguistic diversity increases by 5.5 percentage points between 2006 and 2010, or approximately 20\% of the 2006 sample mean.

\subsection{Other explanatory variables}


We estimate several versions of our main model, progressively increasing the set of independent variables. The choice of independent variables follows the literature and includes: marital and employment status, education level, region of residence, family disposable income, and an index of socio-economic deprivation calculated in HILDA (Summerfield et al 2012). Table 2 lists the variables used in the analysis. Our set of control variables includes some important characteristics that have been omitted in previous studies (Leigh, 2006; Alesina \& La Ferrara, 2002; Putnam, 2007), such as whether the individual lives in urban or rural area. This is an important control variable that can be related with trust and diversity. Urban neighbourhoods are much more likely than rural neighbourhoods to be ethnically or linguistically diverse. If it is the case that individuals from urban neighbourhoods are also systematically more or less trusting than individuals from rural neighbourhoods, then this will be an important source of omitted variable bias in previous studies. Lastly, we include information on residential tenure. A higher residential tenure should increase familiarity among the individual and the individual's neighbours, thereby increasing trust.

Table 3 reports some descriptive statistics for the estimation sample. The mean value of the variables remains consistent between 2006 and 2010. Approximately one-fifth of the sample was born outside of Australia. There is a notable increase in the average household disposable income for the sample from 2006 to 2010 (approximately $+26 \%$ ). Further, the sample seems to be biased towards middle and upper income neighbourhoods, as only $17 \%$ or respondents belong to the two lowest deciles of the socio-economic status distribution.

Table 2 here

Table 3 here 


\section{Methodology and Estimation}

We start with a simple linear model relating trust to various fractionalisation measures at the neighborhood level:

Trust $_{i j}=\alpha_{0}+\beta_{1} X_{i}+\beta_{2} Y_{j}+\beta_{3} F_{j}+u_{i j}$

Where:

Trust $_{i j}$ is the extent to which individual $i$ in neighbourhood $j$ trusts others, either in a broad general sense or in a strict local sense.

$X_{i}$ is a vector of the characteristics of individual $i$.

$Y_{j}$ is a vector of the characteristics of neighbourhood $j$.

$F_{j}$ is a measure of the ethno-linguistic fractionalisation of neighbourhood $j$.

The parameter of interest in the above model is $\beta_{3}$, which provides an estimate of the effect of neighbourhood heterogeneity on individual trust level. The neighbourhood is defined as the area represented by a single postal code in the Australian Census. A range of specifications will be presented so as to separately estimate the effect of neighbourhood diversity on generalized trust and on local trust. Alternative measures of neighbourhood diversity will be used and the effect of ethnic fractionalisation will be compared to the effect of linguistic fractionalisation.

Estimation by OLS could be biased if we are not controlling for variables that are jointly correlated with neighbourhood trust and neighbourhood heterogeneity. Following Leigh (2006) and Alesina \& La Ferrara (2002), we include a number of individual and 
neighbourhood level control variables, such as gender, education levels, income levels, and neighbourhood socio-economic status, as well as some additional characteristics available in HILDA that might have an effect on trust, such as individual cultural background and status as a rural or urban resident. This strategy however cannot account for the unobservable individual characteristics that are jointly correlated with trust levels and neighbourhood diversity. These unobservable characteristics cannot be included as control variables in an OLS model and might bias the results.

One way to overcome the endogeneity bias in this context is to instrument heterogeneity at the neighbourhood level with the heterogeneity of a larger region (local statistical area) containing that neighbourhood, as was done in Leigh (2006). The validity of this instrument is based on the strong assumption that individuals can move between neighbourhoods but are constrained to remain within the larger region, as a result of family or workplace ties. For this reason, we use IV results as a sensitivity test to confirm the OLS findings and we report them only briefly in the results section.

Finally, to account for individual unobserved traits and characteristics that do not vary over time, we control for the individual fixed effects by estimating the following model:

Trust $_{i j}=\alpha_{0}+\beta_{1} X_{i}+\beta_{2} Y_{j}+\beta_{3} F_{j}+u_{i j}+\gamma_{i}$

where $\gamma_{\mathrm{i}}$ is an individual fixed effect that takes into account time-invariant unobserved heterogeneity. The parameter of interest in this model is identified by the changes in the diversity of that individual's neighbourhood. Thus there are two possible sources of identification in the model: (i) changes in the ethnic composition of a given neighbourhood over time, and (ii) relocation of a given individual between different neighbourhoods. One reason to be concerned about this distinction is the possibility of endogenous mobility: 
decisions to move or stay in a given neighbourhood might be motivated by the preferences for ethnic heterogeneity. For example neighbourhood diversity might have a negative effect on trust for a relatively small portion of individuals in the population, but those individuals are more likely to change neighbourhoods. In this case, if the model is identified by movers, the estimates will be valid for that sub-population, but might overstate the average effect for the population. On the other hand, stayers might be comprised of individuals who are indifferent to the ethnic composition of their neighbourhood. If the identifying variation comes from stayers we might expect that the estimates will understate the average effect. To further investigate this issue we will estimate the model separately on the sample of movers and stayers and compare the results to those obtained in the combined sample.

Another potential limitation of a fixed effects model in this context concerns time-specific shocks. Alesina \& La Ferrara (2002) find that shocks or traumatic experiences, such as divorce or financial misfortune, negatively affect how trusting an individual is. Since a fixed effect model can only eliminate time-invariant characteristics, the presence of random timevarying shocks can produce biased estimates. If an individual experiences a trust affecting shock between the two periods, and the shock coincides with or motivates changes in neighbourhood diversity, the model may incorrectly attribute the change in trust to the change in neighbourhood diversity. For example a negative income shock might reduce an individual's trust and necessitate a move to a low-income neighbourhood. This might generate spurious correlation between trust and diversity if income and diversity are negatively correlated at the neighbourhood level. Even though diversity and income are not correlated in our sample, and we are able to control for the observable shocks, one might still be concerned about the role of unobservable time specific shocks. Mitigating this 
potential limitation to some degree, Alesina \& La Ferrara (2002) find that the effects of such shocks typically endure for less than a year, so only shocks occurring close to either survey will be likely to have an effect on trust levels, and the chances of these shocks simultaneously affecting neighbourhood diversity levels are reasonably low.

\section{Results}

This section presents the main empirical findings of the investigation into the effect of neighbourhood heterogeneity on individual trust formation. Results will first be presented for the OLS model, followed by the IV and Fixed Effects model. Results discussed in this section refer to the pooled sample including the observations from 2006 and 2010. Separate results for the two waves are available from the authors on request.

Table 4 presents the results from the OLS regression with generalized trust as a dependent variable and Table 5 presents the results for local trust. In both tables, column 1 shows the results with ethnic fractionalisation included as an explanatory variable along with only basic individual characteristics. In columns 2 we add variables controlling for individual's educational attainment and residential tenure, along with binary variables capturing the relative level of socio-economic disadvantage of the individual's neighbourhood. In column 3 this specification is re-estimated including linguistic diversity as the explanatory variable of interest in place of ethnic diversity. The estimates of the effect of socio-economic disadvantage and educational attainment variables are not presented in the tables for reasons of parsimony, but are available on request. In both tables and in all specifications, the fractionalisation indices are normalised so that the coefficients represent the marginal effect of a one standard deviation increase. Robust standard errors are clustered at postcode level. 
Using the 'benchmark' specification including a more comprehensive set of control variables, the coefficients on both fractionalisation indices are significant at $1 \%$ for local trust and at $5 \%$ for generalized trust. The relationship between fractionalisation and generalized trust is economically trivial. A one standard deviation increase in ethnic fractionalisation is associated with a decrease in generalized trust of 0.032 or approximately $2.4 \%$ of a standard deviation. The results for linguistic fractionalisation are similar. On the other hand, a one standard deviation increase in ethnic fractionalisation decreases local trust by $9 \%$ of a standard deviation. A one standard deviation increase in linguistic heterogeneity decreases local trust by 0.122 , or by $8.7 \%$ of a standard deviation.

Moving from a neighbourhood of complete ethnic homogeneity to a neighbourhood of complete ethnic heterogeneity - from an index score of 0 to an index score of 1 - would reduce local trust by $60 \%$ of a standard deviation.

Considering some of the other variables of interest, women are shown to have higher levels of generalized trust. Generalized trust also slightly decreases with age, and the coefficient of age squared indicates that trust is higher at very young and very old ages, and low at middle-age. The relative socio-economic status of an individual's neighbourhood plays a large role in determining trust, and individuals from the least disadvantaged decile have higher levels of general and local trust than individuals from the most disadvantaged decile. Urban residents have significantly lower levels of general and local trust than people living in rural areas.

Indigenous Australians trust on average less than the sample mean (being indigenous reduces local trust by about $12 \%$ of a standard deviation) and a similar effect is observed for migrants (-5\% of a standard deviation in local trust). Migrants have less general and local 
trust than non-migrants. These findings could plausibly be explained by the enduring effect of culture on trust levels.

Algan and Cahuc (2010) find that inherited trust among US immigrants is highly correlated with the migrant's country of birth. Similarly, the endurance of cultural 'shocks' such as those described by Nunn and Wantchekon (2011) might explain the reduced disposition to trust among an Indigenous population subjected to widespread trauma and injustice in recent history. It is perhaps not surprising that this effect is more pronounced for generalized trust levels than local trust levels. Repeated interaction and familiarity at the local level might promote trust within local communities, but overarching cultural norms might prevent the formation of higher levels of generalized trust.

Table 4 here

Table 5 here

The preferred specification of the model includes many observable variables that might be determinants of trust levels such as, for example, the urban binary variable, household income, and educational attainment. However it is possible that the effect of neighbourhood diversity on trust is introduced by individuals from low trust cultural backgrounds. Since migrants are shown to partially retain the cultural norms of their home countries (Algan \& Cahuc 2010), it is possible that migrants from certain cultural backgrounds will have higher or lower levels of trust than the existing population. Migrants are more likely to be found in high diversity areas. This might mean that the correlation between diversity and trust might not be interpreted causally because the "migrant' binary variable of 'might not be precise or powerful enough to properly control for this phenomenon. 
For this reason, a sensitivity test has been run, where the OLS model is respecified, first to include a binary variable for the country of birth of each respondent and then to include an indicator of the 'region' of birth which allows for greater precision in the estimates where some countries are represented by very few respondents. The complete results are available on request and are very similar to the ones reported above. We therefore conclude that the results do not seem to be driven by the presence of individuals from particular backgrounds in more diverse neighbourhoods.

Further, we have run an additional sensitivity test, by first excluding migrants from our sample and then limiting the estimation to migrants only. Results are reported in Table 11 and, as expected, show that most of the local trust effect is driven by non-migrant individuals, while fractionalisation does not seem to have a significant effect on migrants' trust.

Table 6 and 7 report the results for the sensitivity test using the IV model. The underlying identification assumption in this specification is that individuals are more or less constrained within larger regions by work, family and social ties and therefore the ethnic fractionalisation of a larger region can be used as an instrument for the ethnic or linguistic fractionalisation of smaller regions.

The dependent variables are generalized trust in Table 6, and local trust in Table 7. Column 3 includes linguistic diversity as the explanatory variable of interest. First stage regression results are not presented for reasons of parsimony but are available from the authors on request. In all cases, the $\mathrm{F}$ test statistic shows that the instrument - ethnic heterogeneity of the larger region - is relevant and significant. 
Table 6 here

Table 7 here

The coefficients of interest in the IV model are comparable to those in the OLS model, in terms of the direction and significance of the effect on both local and generalized trust. Relative to the OLS results for generalized and local trust, the magnitude of the effects is slightly larger in the IV model. The results tentatively support the intuition behind the use of the instrumental variable regression as argued by Dustmann and Preston (2001): the endogeneity of neighbourhood choice possibly results in individuals with a larger aversion to heterogeneity systematically sorting themselves into lower-diversity neighbourhoods, thereby potentially biasing the OLS regression estimators toward zero, relative to a sample in which all individuals are allocated across neighbourhoods on a purely random basis.

The results from the fixed effects model are presented in Table 8 and this is our preferred specification. Columns 1,2 and 3 report the results from the fixed effects model using generalized trust as the dependent variable. The distinction between columns is the same as previously reported, with columns 1 and 2 using ethnic fractionalisation and column 3 using linguistic fractionalisation as the explanatory variable of interest. Columns 4,5 and 6 repeat the specifications from the previous three columns, using local trust as the dependent variable.

Since the fixed effects model relies on changes in variables from one time period to the next one as a source of identifying variation, all variables that are both time-invariant and entityinvariant, such as gender and migrant status, are omitted from the model. Similarly, controlling for time fixed effects by including a binary variable for year 2006 implies that the 
'age' variable is dropped from the model, as the variation in age from one time period to the next is perfectly correlated with the variation in time between 2006 and 2010.

Table 8 here

Using fixed effects to control for unobservable time and individual characteristics, the effect of ethnic or linguistic diversity on generalized trust loses significance. The coefficients on the diversity indicators for the three specifications which include generalized trust as the dependent variable fall to practically zero. However, even after accounting for the unobservable individual characteristics, the effect of neighbourhood ethno-linguistic fractionalisation on local trust levels is negative and highly significant. The effect of ethnolinguistic fractionalisation on local trust in the fixed effects model is approximately consistent with the effects reported in the OLS model. One standard deviation increase in ethnic diversity leads to a decrease in local trust by $12 \%$ of a standard deviation. The effect is reduced to $10.7 \%$ of a standard deviation where linguistic fractionalisation is the chosen measure of neighbourhood heterogeneity.

For example, a postcode with an index of ethnic fractionalisation equal to 0.81 , like Lakemba in Sydney (New South Wales), has a predicted average level of local trust of 3.71 (measured on a range 1-7), while a postcode with a level of ethnic fractionalisation of 0.66 (for example St Ives in NSW) has a predicted average level of local trust of 4.72. Similarly, the suburb of Footscray in Melbourne (Victoria) has a high level of ethnic fractionalisation (average index equal to 0.76 ) and predicted average local trust equal to 3.68 , while Toorak (Melbourne, VIC) has a lower level of ethnic fractionalisation (index equal to 0.58) and higher level of predicted local trust (4.74). 
An interesting way to interpret the magnitude of these effects is to analyse them by looking at previous studies which discuss the relationship between trust and other important economic variables. For example, Knack and Keefer (1997) show that a one standard deviation increase in trust determines a change in growth of more than one-half of a standard deviation. However, their study refers to the impact of generalized trust, while most of the effect of ethnic fractionalisation is found on local trust in the current analysis.

In interpreting the results of the fixed effects model, it is important to first consider what drives the results, and what provides the source of identifying variation. In this case, changes in the neighbourhood diversity variable are the result of either an evolution of a neighbourhood's ethnic composition over time, or the result of an individual moving between neighbourhoods between the two time periods. To investigate the relative importance of the two sources of identification we will run separate regressions on two subsamples; the movers and the stayers. If the effect of diversity on trust is systematically different for movers relative to stayers, the coefficients estimated for the two distinct subsamples should be significantly different. Table 9 presents the results of this analysis. Column 1 shows the results for the same fixed effect model estimated in Table 8 (columns 5 and 6), for ease of comparison. Column 2 repeats the estimation using only the subsample of stayers. This has the effect of dropping certain variables from the regression such as the urban dummy since the source of identifying variation is lost. Column 3 performs the same regression on the subsample of movers only.

Table 9 here

The interpretation of results presented in Table 9 is that the fixed effects results are not substantially different for those individuals who changed neighbourhoods between the two 
waves and those who did not. The magnitude and direction of the effect of ethnic fractionalisation is consistent with the other estimations. Further, the coefficients from the subsample of movers and non-movers are not significantly different from the coefficients from the whole sample. The lower level of significance can be attributed to the relatively slow evolution of a neighbourhood's ethnic fractionalisation in such a short period of time which results in a relatively small variation in the fractionalisation index between the two censuses. The results are largely mirrored for the effect of linguistic fractionalisation, though the estimator in column 2 drops to practically zero. This can again be attributed to a lack of precision and estimation power in the data. Unlike the effect of ethnic fractionalisation on local trust, the coefficients for linguistic fractionalisation differ between the movers and the stayers. The effect is larger for the subsample of movers relative to the whole-of-sample effect. This implies that the effect of linguistic diversity effect is driven primarily by movers. The magnitude of the effect is as high as $15 \%$ of a standard deviation.

\subsection{Alternative measures: generalized trust and neighbourhood coherence}

As discussed above, we also perform the analysis using a set of dependent variables which can be thought of as proxies for general belief in the moral standards of other people and measures of local neighbourhood level social capital which might impact on the local or strategic trust at the neighbourhood level. The results are reported in Table 10. A coefficient is reported for the effect of both ethnic and linguistic fractionalisation on each variable. Each column represents a different dependent variable as follows.

1. "Most people would try to take advantage of you if they got a chance."

2. "Most people you meet keep their word."

3. "Most people you meet make agreements honestly." 
4. "This is a close-knit neighbourhood."

5. "People in this neighbourhood generally do not get along."

6. "People in this neighbourhood generally do not share the same values."

As explained in section 3.1, we use these alternative questions primarily to enrich the analysis by investigating whether these new variables respond to diversity in ways which are similar to the trust indicators. The first three questions capture the belief in the moral qualities of other people with whom the respondent is not necessarily familiar, and therefore can be seen as alternative proxies for generalized trust.

On the other hand, the last three questions are related to measures of the social cohesion of the neighbourhood in which a respondent resides to supplement the analysis of the local or strategic trust. This set of questions is a subset of the questions used by Sampson et al (1997).

\section{Table 10 here}

The results reported in table 10 generally confirm the conclusions drawn from the previous models that used the more direct questions regarding trust as the dependent variables. The effect of neighbourhood ethnic or linguistic heterogeneity on the first set of variables (1-3) is not significantly different from zero. On the other hand, ethnic fractionalisation has a significant and consistently negative relationship with perceptions of local community togetherness, noting that questions five and six are framed such that a positive coefficient is indicative of a negative perception of the neighbourhood. The effect for questions 5 and 6 are consistent with or slightly larger than the reported effect on local trust, though the effect reported under column 4 is noticeably larger. When linguistic fractionalisation is 
considered as the explanatory variable of interest, a broadly similar story emerges, though the effect is lessened by approximately one to one and half percentage points across the three neighbourhood level variables.

\section{Conclusion}

This paper has studied the determinants of generalized trust (Uslaner, 2002) and local trust in Australia using a variety of econometric techniques and identifying assumptions. The results are uniform across practically all specifications and indicate that neighbourhood level diversity affects local or strategic trust but has no effect on generalized trust. These results are consistent with the findings reported in Leigh (2006) who used Australian survey data from the 1990s. In all specifications, an increase in neighbourhood diversity is associated with a decrease in local trust, for both ethnic and linguistic diversity. The estimated effect remains consistent when the IV and fixed effects models are used. Neighbourhood ethnic or linguistic heterogeneity is among the most important determinants of local trust identified in the models. There is no consistent evidence of the effect of neighbourhood diversity on generalized trust. The relationship appears to be significant in some of the OLS specifications, however the fixed effects model, using the combined longitudinal sample, produces estimates that are not significantly different to zero.

Results from the fixed effects model (the most credible identification strategy) tend to suggest that neighbourhood diversity does not have any significant effect on respondent's beliefs in the moral qualities of people in general as captured by the generalized trust question. Overall our results indicate that while the negative effects of ethnic diversity on 
trust in Australia are relatively limited, there might be a scope for government policies aimed at lowering cultural barriers in ethnically diverse areas 


\section{References}

Acemoglu, D. and Wolitzky, A. (2014) 'Cycles of Conflict: An Economic Model', The American Economic Review, 104, 1350-1367.

Aghion, P., Algan, Y., Cahuc, P. and Shleifer, A. (2010) 'Regulation and Distrust', Quarterly Journal of Economics, 125, 1015-1049.

Aghion, P., Algan, Y., Cahuc, P. (2011) 'Can Policy Affect Culture: Minimum Wage and the Quality of Labor Relations', Journal of the European Economic Association, 9, 3-42.

Alesina, A. and La Ferrara, E. (2002) 'Who Trusts Others?', Journal of Public Economics, 85, 207-234.

Algan, Y and Cahuc, P. (2010) 'Inherited Trust and Growth', American Economic Review, 100, 2060-2092.

Algan, Y and Cahuc, P. (2013) 'Trust and Growth', Annual Review of Economics 2013, 5, 52149.

Arrow, K. (1972) 'Gifts and Exchanges' Philosophy and Public Affairs, 1, 343-362

Australian Bureau of Statistics (2006) Census of Population and Housing - Basic Community Profiles cat. no. 2069.0.30.

Australian Bureau of Statistics (2011) Census of Population and Housing - Basic Community Profiles.

Australian Bureau of Statistics (2013) Migration, Australia, 2011-12 and 2012-13, cat. no. 3412.0, ABS, Canberra.

Barnes, A. (2001) Occasional Paper No. 2 - Low Fertility: A Discussion Paper, Department of Family and Community Services.

Berg, Joyce, John Dickhaut, and Kevin McCabe, (1995) "Trust, Reciprocity, and Social

History," Games and Economic Behavior, X, 122-142.

Bullen, P., \& Onyx, J. (1999). Social capital: Family support services and neighbourhood and 
community centres in NSW. Local Community Services Association.

Castles, S. (1992) "The Australian Model of Immigration and Multiculturalism: Is It Applicable to Europe?" The International Migration Review, 26 (2), 549-567.

Dasgupta, P (1988) "Trust as a Commodity", in Gambetta D. ed., "Trust: Making and Breaking Cooperative Relations", Blackwell.

Delhey, J. and Newton, K. (2005) 'Predicting Cross-National Levels of Social Trust. Global Pattern or Nordic Exceptionalism?', European Sociological Review, 21 (4), 311-27.

Desmet, K., Ortuno-Ortin, I. and Wacziarg, R. (2012) 'The Political Economy of Linguistic Cleavages', Journal of Development Economics, 97, 322-38.

Dustmann, C. \& Preston, I. (2001) 'Attitudes to Ethnic Minorities, Ethnic Context and Location Decisions', The Economic Journal, 111, 353-373.

Fehr, E.; Fishbacher, U.; von Rosenbladt, B.; Schupp, J.; Wagner, G. (2003). A Nation-Wide Laboratory Examining Trust and Trustworthiness by Integrating Behavioral Experiments into Representative Surveys. CESifo Working Paper 866, Munich.

Glaeser, E., Laibson, D., Scheinkman, J. And Soutter, C. (2000) 'Measuring Trust', Quarterly Journal of Economics, 65, 811-846.

Knack, S. and Keefer, P. (1997) 'Does Social Capital Have an Economic Payoff? A CrossCountry Investigation', Quarterly Journal of Economics, 112, 1251-1288.

La Porta, R., Lopez-de-Silanes, F., Shleifer, A. and Vishny, R. (1999), 'The Quality of Government', Journal of Law, Economics, and Organization, 15(1), 222-79.

Leigh, A. (2006) 'Trust, Inequality and Ethnic Heterogeneity', The Economic Record, 82, 268-280.

Nunn, N. and Wantchekon, L. (2011) 'The Slave Trade and the Origins of Mistrust in Africa', American Economic Review, 101, 3221-3252.

OECD (2006), International Migration Outlook: SOPEMI - 2006 Edition, OECD, Paris 
Phillips, J., Klapdor, M. and Simon-Davies, J. (2010) Migration to Australia Since Federation: A Guide to the Statistics, Department of Parliamentary Services.

Putnam, R. (2007) 'E Pluribus Unum: Diversity and Community in the Twenty-first Century The 2006 Johan Skytte Prize Lecture', Scandinavian Political Studies, 30, 137-174.

Soroka, S., Helliwell, J. and Johnston, R. (2007) 'Measuring and Modeling Interpersonal Trust' in Kay, F. and Johnston, R., eds, Social Capital, Diversity and the Welfare State, UBC Press, Vancouver.

Patrick Sturgis and Patten Smith, (2010) 'Assessing the Validity of Generalized Trust Questions: What Kind of Trust Are We Measuring?' International Journal of Public Opinion Research.

Sturgis, P., Brunton-Smith, I., Read, S. and Allum, N. (2011) 'Does Ethnic Diversity Erode Trust? Putnam's 'Hunkering Down' Thesis Reconsidered' British Journal of Political Science, $41,57-82$.

Summerfield, M., Freidin, S., Hahn, M., Ittak, P., Li, N., Macalalad, N., Watson, N., Wilkins, R. and Wooden, M. (2012) HILDA User Manual - Release 11, Melbourne Institute of Applied Economic and Social Research, University of Melbourne.

Tabellini, G. (2008) 'The Scope of Cooperation: Values and Incentives' Quarterly Journal of Economics, 123, 905-950.

Uslaner, E. M. (2002). The Moral Foundations of Trust. New York: Cambridge University Press.

Wang, C. and Steiner, B. (2015) 'Can Ethno-Linguistic Diversity Explain Cross-Country Differences in Social Capital?: A Global Perspective' , Economic Record, 91, 338-366.

Williamson, Oliver E. (1993). Calculativeness, Trust, and Economic Organization. Journal of Law \& Economics, 36(1), 453-486. 


\section{Tables}

Table 1 - Trust variables

\begin{tabular}{lcc}
\multicolumn{1}{c}{ Variable } & Mean & Standard Deviation \\
\hline Generalized trust & 4.887 & 1.301 \\
$\begin{array}{l}\text { Local Trust } \\
\text { "Most people would take }\end{array}$ & 4.698 & 1.393 \\
$\begin{array}{l}\text { advantage of you" } \\
\text { "Most people you meet keep }\end{array}$ & 3.290 & 1.715 \\
$\begin{array}{l}\text { their word" } \\
\text { "Most people make agreements }\end{array}$ & 4.699 & 1.375 \\
$\begin{array}{l}\text { honestly" } \\
\text { "This is a close-knit } \\
\text { neighbourhood" }\end{array}$ & 4.989 & 1.263 \\
$\begin{array}{l}\text { "People in this neighbourhood } \\
\text { generally don't get along" } \\
\text { "People in this neighbourhood } \\
\text { generally don't share the same } \\
\text { values" }\end{array}$ & 3.911 & 1.482 \\
\hline
\end{tabular}


Table 2 - Variables used in the analysis

\begin{tabular}{|c|c|}
\hline $\begin{array}{l}\text { Individual } \\
\text { characteristics }\end{array}$ & Description \\
\hline Post code & Individual's postcode \\
\hline $\begin{array}{l}\text { Neighbourhood section } \\
\text { of state }\end{array}$ & Urban or Non-Urban (omitted) \\
\hline $\begin{array}{l}\text { Indigenous Australian } \\
\text { Status }\end{array}$ & Indigenous Australian or Non Indigenous (omitted) \\
\hline Age & Individual's age in years at interview \\
\hline Gender & Female or Male (omitted) \\
\hline Employment status & Unemployed, Not in the Labour force, Employed (omitted) \\
\hline $\begin{array}{l}\text { Parental status } \\
\text { Weekly commuting } \\
\text { hours }\end{array}$ & $\begin{array}{l}\text { Parent or never had children (omitted) } \\
\text { Average hours per week usually commuting (range 0-30) }\end{array}$ \\
\hline Weekly working hours & Average hours per week usually worked (range 0-112) \\
\hline $\begin{array}{l}\text { Highest educational } \\
\text { attainment }\end{array}$ & $\begin{array}{l}\text { Postgraduate qualification; Graduate Diploma or Certificate; Bachelor; Diploma; } \\
\text { Certificate III or IV, Year 12, Year } 11 \text { or lower (omitted) }\end{array}$ \\
\hline Country of birth & Binary variable \\
\hline $\begin{array}{l}\text { Length of residential } \\
\text { tenure }\end{array}$ & Number of years living at current address \\
\hline $\begin{array}{l}\text { Relative Neighbourhood } \\
\text { disadvantage }\end{array}$ & Decile of index of relative socio-economic disadvantage \\
\hline Household income & Household financial year disposable income $(\$ 10,000$ units) \\
\hline
\end{tabular}

Table 3 - Descriptive statistics

2006

2010

\begin{tabular}{lcccc}
\hline \multicolumn{1}{c}{ Variable } & Mean & Std. Dev. & Mean & Std. Dev. \\
Age & 43.9804 & 18.2135 & 44.1425 & 18.5340 \\
Female & 0.5334 & 0.4989 & 0.5223 & 0.4995 \\
Aboriginal/Torres Strait Islander & 0.0197 & 0.1389 & 0.0226 & 0.1488 \\
Migrant & 0.2041 & 0.4031 & 0.1939 & 0.3954 \\
Unemployed & 0.0332 & 0.1791 & 0.0372 & 0.1892 \\
Not in Labour Force & 0.3235 & 0.4678 & 0.3289 & 0.4698 \\
Household Income $(\$)$ & $66,933.94$ & $50,075.57$ & $84,460.05$ & $63,659.50$ \\
Parent & 0.6520 & 0.4764 & 0.6448 & 0.4786 \\
Hours Commuted per Week & 2.3240 & 3.6455 & 2.5087 & 3.8367 \\
Hours Worked per Week & 23.4735 & 21.4474 & 22.9908 & 21.0477 \\
Years at Current Address & 9.9678 & 11.3737 & 9.9286 & 11.2380 \\
Urban Resident & 0.6080 & 0.4882 & 0.6073 & 0.4884 \\
\hline
\end{tabular}


Table 4 - OLS Estimation - Dependent Variable: Generally speaking, most people can be trusted.

\begin{tabular}{|c|c|c|c|}
\hline VARIABLES & (1) & (2) & (3) \\
\hline Ethnic Fractionalisation & $\begin{array}{l}-0.027^{*} \\
(0.014)\end{array}$ & $\begin{array}{c}-0.032 * * \\
(0.015)\end{array}$ & \\
\hline Linguistic & & & $-0.028 * *$ \\
\hline Fractionalisation & & & $(0.014)$ \\
\hline Female & $\begin{array}{c}0.078 * * * \\
(0.020)\end{array}$ & $\begin{array}{c}0.059 * * * \\
(0.019)\end{array}$ & $\begin{array}{c}0.059 * * * \\
(0.019)\end{array}$ \\
\hline Age & $\begin{array}{l}-0.005 \\
(0.003)\end{array}$ & $\begin{array}{c}-0.009 * * \\
(0.003)\end{array}$ & $\begin{array}{c}-0.009 * * \\
(0.003)\end{array}$ \\
\hline $\mathrm{Age}^{\wedge} 2$ & $\begin{array}{c}0.000 * * * \\
(0.000)\end{array}$ & $\begin{array}{c}0.000 * * * \\
(0.000)\end{array}$ & $\begin{array}{c}0.000^{* * *} \\
(0.000)\end{array}$ \\
\hline Indigenous Australian & $\begin{array}{c}-0.350 * * * \\
(0.082)\end{array}$ & $\begin{array}{c}-0.260 * * * \\
(0.081)\end{array}$ & $\begin{array}{c}-0.259 * * * \\
(0.081)\end{array}$ \\
\hline Migrant & $\begin{array}{c}-0.160^{* * *} \\
(0.027)\end{array}$ & $\begin{array}{c}-0.167^{* * *} \\
(0.027)\end{array}$ & $\begin{array}{c}-0.170 * * * \\
(0.026)\end{array}$ \\
\hline Unemployed & $\begin{array}{c}-0.429 * * * \\
(0.064)\end{array}$ & $\begin{array}{c}-0.378 * * * \\
(0.063)\end{array}$ & $\begin{array}{c}-0.378^{* * *} \\
(0.063)\end{array}$ \\
\hline Not in Labour Force & $\begin{array}{c}-0.243^{* * *} \\
(0.036)\end{array}$ & $\begin{array}{c}-0.195 * * * \\
(0.036)\end{array}$ & $\begin{array}{c}-0.195 * * * \\
(0.036)\end{array}$ \\
\hline Parent & $\begin{array}{l}-0.044 \\
(0.029)\end{array}$ & $\begin{array}{l}-0.000 \\
(0.028)\end{array}$ & $\begin{array}{c}0.000 \\
(0.028)\end{array}$ \\
\hline $\begin{array}{l}\text { Household Income } \\
(10000)\end{array}$ & $\begin{array}{c}0.021 * * * \\
(0.002)\end{array}$ & $\begin{array}{c}0.012 * * * \\
(0.002)\end{array}$ & $\begin{array}{c}0.012^{* * *} \\
(0.002)\end{array}$ \\
\hline $\begin{array}{l}\text { Hours Worked per } \\
\text { Week }\end{array}$ & $\begin{array}{c}-0.002 * * \\
(0.001)\end{array}$ & $\begin{array}{c}-0.002 * * \\
(0.001)\end{array}$ & $\begin{array}{c}-0.002^{* *} \\
(0.001)\end{array}$ \\
\hline Hours Commute per & $-0.008 * * *$ & $-0.008 * * *$ & $-0.008 * * *$ \\
\hline Week & $(0.003)$ & $(0.003)$ & $(0.003)$ \\
\hline Wave 1 (2006) & $\begin{array}{l}-0.014 \\
(0.017)\end{array}$ & $\begin{array}{l}-0.029^{*} \\
(0.017)\end{array}$ & $\begin{array}{l}-0.019 \\
(0.018)\end{array}$ \\
\hline $\begin{array}{l}\text { Residential Tenure } \\
\text { (Years) }\end{array}$ & & $\begin{array}{c}0.003 * * * \\
(0.001)\end{array}$ & $\begin{array}{c}0.003^{* * *} \\
(0.001)\end{array}$ \\
\hline Urban & & $\begin{array}{c}-0.087^{* * *} \\
(0.030)\end{array}$ & $\begin{array}{c}-0.095^{* * *} \\
(0.028)\end{array}$ \\
\hline Observations & 21,255 & 21,255 & 21,255 \\
\hline R-squared & 0.066 & 0.087 & 0.087 \\
\hline Education Controls & NO & YES & YES \\
\hline SES Controls & NO & YES & YES \\
\hline $\begin{array}{l}\text { Dependent Variable } \\
\text { Mean }\end{array}$ & 4.887 & 4.887 & 4.887 \\
\hline
\end{tabular}

Note: Robust standard errors in parentheses. ${ }^{* * *} p<0.01,{ }^{* *} p<0.05,{ }^{*} p<0.1$ 
Table 5 - OLS Estimation - Dependent Variable: People in this neighbourhood can be trusted

\begin{tabular}{|c|c|c|c|}
\hline VARIABLES & (1) & (2) & (3) \\
\hline Ethnic Fractionalisation & $\begin{array}{c}-0.176^{* * *} \\
(0.019)\end{array}$ & $\begin{array}{c}-0.130 * * * \\
(0.019)\end{array}$ & \\
\hline Linguistic & & & $-0.122 * * *$ \\
\hline Fractionalisation & & & $(0.018)$ \\
\hline Female & $\begin{array}{l}0.006 \\
(0.020)\end{array}$ & $\begin{array}{l}-0.009 \\
(0.019)\end{array}$ & $\begin{array}{l}-0.008 \\
(0.019)\end{array}$ \\
\hline Age & $\begin{array}{c}0.003 \\
(0.004)\end{array}$ & $\begin{array}{c}0.002 \\
(0.004)\end{array}$ & $\begin{array}{l}0.002 \\
(0.004)\end{array}$ \\
\hline $\mathrm{Age}^{\wedge} 2$ & $\begin{array}{c}0.000 * * * \\
(0.000)\end{array}$ & $\begin{array}{c}0.000 * * * \\
(0.000)\end{array}$ & $\begin{array}{c}0.000 * * * \\
(0.000)\end{array}$ \\
\hline Indigenous Australian & $\begin{array}{c}-0.346 * * * \\
(0.087)\end{array}$ & $\begin{array}{c}-0.171^{* *} \\
(0.086)\end{array}$ & $\begin{array}{l}-0.167^{*} \\
(0.086)\end{array}$ \\
\hline Migrant & $\begin{array}{c}-0.100 * * * \\
(0.028)\end{array}$ & $\begin{array}{c}-0.077^{* * *} \\
(0.028)\end{array}$ & $\begin{array}{c}-0.086^{* * *} \\
(0.029)\end{array}$ \\
\hline Unemployed & $\begin{array}{c}-0.298 * * * \\
(0.071)\end{array}$ & $\begin{array}{c}-0.212 * * * \\
(0.067)\end{array}$ & $\begin{array}{c}-0.212^{* * *} \\
(0.067)\end{array}$ \\
\hline Not in Labour Force & $\begin{array}{c}-0.112 * * * \\
(0.038)\end{array}$ & $\begin{array}{l}-0.038 \\
(0.037)\end{array}$ & $\begin{array}{l}-0.037 \\
(0.037)\end{array}$ \\
\hline Parent & $\begin{array}{c}0.035 \\
(0.030)\end{array}$ & $\begin{array}{c}0.085^{* * *} \\
(0.029)\end{array}$ & $\begin{array}{c}0.085^{* * *} \\
(0.029)\end{array}$ \\
\hline $\begin{array}{l}\text { Household Income } \\
(10000)\end{array}$ & $\begin{array}{c}0.026 * * * \\
(0.004)\end{array}$ & $\begin{array}{c}0.009 * * * \\
(0.002)\end{array}$ & $\begin{array}{c}0.009 * * * \\
(0.002)\end{array}$ \\
\hline Hours Worked per & $-0.002 * *$ & $-0.002 * *$ & $-0.002 *$ \\
\hline Week & (0.001) & $(0.001)$ & $(0.001)$ \\
\hline Hours Commute per & -0.004 & -0.002 & -0.002 \\
\hline Week & $(0.003)$ & $(0.003)$ & $(0.003)$ \\
\hline Wave 1 (2006) & $\begin{array}{c}0.011 \\
(0.020)\end{array}$ & $\begin{array}{l}-0.029 \\
(0.019)\end{array}$ & $\begin{array}{c}0.013 \\
(0.020)\end{array}$ \\
\hline $\begin{array}{l}\text { Residential Tenure } \\
\text { (Years) }\end{array}$ & & $\begin{array}{c}0.008^{* * *} \\
(0.001)\end{array}$ & $\begin{array}{c}0.009 * * * \\
(0.001)\end{array}$ \\
\hline Urban & & $\begin{array}{c}-0.281 * * * \\
(0.038)\end{array}$ & $\begin{array}{c}-0.305^{* * *} \\
(0.036)\end{array}$ \\
\hline Observations & 21,255 & 21,255 & 21,255 \\
\hline R-squared & 0.078 & 0.135 & 0.135 \\
\hline Education Controls & NO & YES & YES \\
\hline SES Controls & NO & YES & YES \\
\hline $\begin{array}{l}\text { Dependent Variable } \\
\text { Mean }\end{array}$ & 4.698 & 4.698 & 4.698 \\
\hline
\end{tabular}

Note: Robust standard errors in parentheses. ${ }^{* * *} \mathrm{p}<0.01,{ }^{* *} \mathrm{p}<0.05,{ }^{*} \mathrm{p}<0.1$ 
Table 6 - IV Estimation - Dependent Variable: Generally speaking, most people can be trusted.

\begin{tabular}{|c|c|c|c|}
\hline VARIABLES & $(1)$ & $(2)$ & (3) \\
\hline Ethnic Fractionalisation & $\begin{array}{l}-0.0127 \\
(0.0176)\end{array}$ & $\begin{array}{c}-0.0520^{* *} \\
(0.0237)\end{array}$ & \\
\hline $\begin{array}{l}\text { Linguistic } \\
\text { Fractionalisation }\end{array}$ & & & $\begin{array}{c}-0.0657^{* *} \\
(0.0301)\end{array}$ \\
\hline Female & $\begin{array}{c}0.0764 * * * \\
(0.0195)\end{array}$ & $\begin{array}{c}0.0586 * * * \\
(0.0192)\end{array}$ & $\begin{array}{c}0.0598 * * * \\
(0.0192)\end{array}$ \\
\hline Age & $\begin{array}{l}-0.00409 \\
(0.00350)\end{array}$ & $\begin{array}{c}-0.00808^{* *} \\
(0.00355)\end{array}$ & $\begin{array}{c}-0.00806 * * \\
(0.00355)\end{array}$ \\
\hline $\mathrm{Age}^{\wedge} 2$ & $\begin{array}{c}0.000241 * * * \\
(3.53 e-05)\end{array}$ & $\begin{array}{c}0.000262^{* * *} \\
(3.62 \mathrm{e}-05)\end{array}$ & $\begin{array}{c}0.000261 * * * \\
(3.62 \mathrm{e}-05)\end{array}$ \\
\hline Indigenous Australian & $\begin{array}{c}-0.323 * * * \\
(0.0825)\end{array}$ & $\begin{array}{c}-0.233^{* * *} \\
(0.0818)\end{array}$ & $\begin{array}{c}-0.233 * * * \\
(0.0819)\end{array}$ \\
\hline Migrant & $\begin{array}{c}-0.168 * * * \\
(0.0279)\end{array}$ & $\begin{array}{c}-0.160 * * * \\
(0.0277)\end{array}$ & $\begin{array}{c}-0.158^{* * *} \\
(0.0279)\end{array}$ \\
\hline Unemployed & $\begin{array}{c}-0.427^{* * *} \\
(0.0650)\end{array}$ & $\begin{array}{c}-0.373^{* * *} \\
(0.0638)\end{array}$ & $\begin{array}{c}-0.373 * * * \\
(0.0638)\end{array}$ \\
\hline Not in Labour Force & $\begin{array}{c}-0.233^{* * *} \\
(0.0362)\end{array}$ & $\begin{array}{c}-0.182 * * * \\
(0.0354)\end{array}$ & $\begin{array}{c}-0.181 * * * \\
(0.0354)\end{array}$ \\
\hline Parent & $\begin{array}{l}-0.0475 \\
(0.0294)\end{array}$ & $\begin{array}{l}-0.00866 \\
(0.0288)\end{array}$ & $\begin{array}{l}-0.0114 \\
(0.0290)\end{array}$ \\
\hline $\begin{array}{l}\text { Household Income } \\
(10000)\end{array}$ & $\begin{array}{l}0.0213^{* * *} \\
(0.00242)\end{array}$ & $\begin{array}{l}0.0120 * * * \\
(0.00188)\end{array}$ & $\begin{array}{l}0.0120 * * * \\
(0.00188)\end{array}$ \\
\hline $\begin{array}{l}\text { Hours Worked per } \\
\text { Week }\end{array}$ & $\begin{array}{l}-0.00175^{* *} \\
(0.000876)\end{array}$ & $\begin{array}{l}-0.00196 * * \\
(0.000855)\end{array}$ & $\begin{array}{l}-0.00189 * * \\
(0.000859)\end{array}$ \\
\hline $\begin{array}{l}\text { Hours Commute per } \\
\text { Week }\end{array}$ & $\begin{array}{c}-0.00830 * * * \\
(0.00277)\end{array}$ & $\begin{array}{c}-0.00757 * * * \\
(0.00273)\end{array}$ & $\begin{array}{c}-0.00776^{* * *} \\
(0.00274)\end{array}$ \\
\hline Wave 1 (2006) & $\begin{array}{l}-0.00814 \\
(0.0174)\end{array}$ & $\begin{array}{l}-0.0258 \\
(0.0170)\end{array}$ & $\begin{array}{l}-0.00123 \\
(0.0216)\end{array}$ \\
\hline $\begin{array}{l}\text { Residential Tenure } \\
\text { (Years) }\end{array}$ & & $\begin{array}{c}0.00332^{* * *} \\
(0.00104)\end{array}$ & $\begin{array}{c}0.00355^{* * *} \\
(0.00105)\end{array}$ \\
\hline Urban & & $\begin{array}{l}-0.0601 \\
(0.0375)\end{array}$ & $\begin{array}{l}-0.0500 \\
(0.0412)\end{array}$ \\
\hline Observations & 20,767 & 20,767 & 20,767 \\
\hline R-squared & 0.066 & 0.087 & 0.087 \\
\hline Education Controls & NO & YES & YES \\
\hline SES Controls & NO & YES & YES \\
\hline
\end{tabular}


Table 7 - IV Estimation - Dependent Variable: People in this neighbourhood can be trusted

\begin{tabular}{|c|c|c|c|}
\hline VARIABLES & (1) & (2) & (3) \\
\hline Ethnic Fractionalisation & $\begin{array}{c}-0.147^{* * *} \\
(0.024)\end{array}$ & $\begin{array}{c}-0.150 * * * \\
(0.030)\end{array}$ & \\
\hline Linguistic & & & $-0.189 * * *$ \\
\hline Fractionalisation & & & $(0.039)$ \\
\hline Female & $\begin{array}{c}0.001 \\
(0.020)\end{array}$ & $\begin{array}{l}-0.012 \\
(0.019)\end{array}$ & $\begin{array}{l}-0.009 \\
(0.020)\end{array}$ \\
\hline Age & $\begin{array}{c}0.004 \\
(0.004)\end{array}$ & $\begin{array}{c}0.003 \\
(0.004)\end{array}$ & $\begin{array}{c}0.003 \\
(0.004)\end{array}$ \\
\hline $\mathrm{Age}^{\wedge} 2$ & $\begin{array}{c}0.000 * * * \\
(0.000)\end{array}$ & $\begin{array}{c}0.000 * * * \\
(0.000)\end{array}$ & $\begin{array}{c}0.000 * * * \\
(0.000)\end{array}$ \\
\hline Indigenous Australian & $\begin{array}{c}-0.337 * * * \\
(0.088)\end{array}$ & $\begin{array}{l}-0.165^{*} \\
(0.086)\end{array}$ & $\begin{array}{l}-0.163^{*} \\
(0.086)\end{array}$ \\
\hline Migrant & $\begin{array}{c}-0.111 * * * \\
(0.030)\end{array}$ & $\begin{array}{c}-0.060 * * \\
(0.029)\end{array}$ & $\begin{array}{l}-0.057^{*} \\
(0.029)\end{array}$ \\
\hline Unemployed & $\begin{array}{c}-0.300 * * * \\
(0.072)\end{array}$ & $\begin{array}{c}-0.209 * * * \\
(0.068)\end{array}$ & $\begin{array}{c}-0.210^{* * *} \\
(0.068)\end{array}$ \\
\hline Not in Labour Force & $\begin{array}{c}-0.115^{* * *} \\
(0.039)\end{array}$ & $\begin{array}{l}-0.039 \\
(0.037)\end{array}$ & $\begin{array}{l}-0.035 \\
(0.037)\end{array}$ \\
\hline Parent & $\begin{array}{c}0.034 \\
(0.031)\end{array}$ & $\begin{array}{c}0.074^{* *} \\
(0.030)\end{array}$ & $\begin{array}{r}0.066^{* *} \\
(0.030)\end{array}$ \\
\hline $\begin{array}{l}\text { Household Income } \\
(10000)\end{array}$ & $\begin{array}{c}0.025^{* * *} \\
(0.004)\end{array}$ & $\begin{array}{c}0.009 * * * \\
(0.002)\end{array}$ & $\begin{array}{c}0.009 * * * \\
(0.002)\end{array}$ \\
\hline $\begin{array}{l}\text { Hours Worked per } \\
\text { Week }\end{array}$ & $\begin{array}{c}-0.002 * * \\
(0.001)\end{array}$ & $\begin{array}{c}-0.002 * * \\
(0.001)\end{array}$ & $\begin{array}{l}-0.002 * \\
(0.001)\end{array}$ \\
\hline $\begin{array}{l}\text { Hours Commute per } \\
\text { Week }\end{array}$ & $\begin{array}{l}-0.005 \\
(0.003)\end{array}$ & $\begin{array}{l}-0.001 \\
(0.003)\end{array}$ & $\begin{array}{l}-0.002 \\
(0.003)\end{array}$ \\
\hline Wave 1 (2006) & $\begin{array}{c}0.015 \\
(0.021)\end{array}$ & $\begin{array}{l}-0.031 \\
(0.019)\end{array}$ & $\begin{array}{c}0.039 \\
(0.024)\end{array}$ \\
\hline $\begin{array}{l}\text { Residential Tenure } \\
\text { (Years) }\end{array}$ & & $\begin{array}{c}0.008^{* * *} \\
(0.001)\end{array}$ & $\begin{array}{c}0.009 * * * \\
(0.001)\end{array}$ \\
\hline Urban & & $\begin{array}{c}-0.258^{* * *} \\
(0.048)\end{array}$ & $\begin{array}{c}-0.229 * * * \\
(0.054)\end{array}$ \\
\hline Observations & 20,767 & 20,767 & 20,767 \\
\hline R-squared & 0.077 & 0.135 & 0.134 \\
\hline Education Controls & NO & YES & YES \\
\hline SES Controls & NO & YES & YES \\
\hline
\end{tabular}


Table 8 - Fixed effects estimates - Effect of fractionalisation on local and generalized trust

\begin{tabular}{|c|c|c|c|c|c|c|}
\hline VARIABLES & $\begin{array}{c}(1) \\
\text { Generalized trust } \\
\end{array}$ & $\begin{array}{c}(2) \\
\text { Generalized trust } \\
\end{array}$ & $\begin{array}{c}(3) \\
\text { Generalized trust } \\
\end{array}$ & $\begin{array}{c}\text { (4) } \\
\text { Local Trust }\end{array}$ & $\begin{array}{c}(5) \\
\text { Local Trust }\end{array}$ & $\begin{array}{c}\text { (6) } \\
\text { Local Trust }\end{array}$ \\
\hline Ethnic Fractionalisation & $\begin{array}{c}0.004 \\
(0.028)\end{array}$ & $\begin{array}{l}-0.003 \\
(0.033)\end{array}$ & & $\begin{array}{c}-0.242^{* * *} \\
(0.031)\end{array}$ & $\begin{array}{c}-0.170 * * * \\
(0.038)\end{array}$ & \\
\hline $\begin{array}{l}\text { Linguistic } \\
\text { Fractionalisation }\end{array}$ & & & $\begin{array}{l}-0.012 \\
(0.028)\end{array}$ & & & $\begin{array}{c}-0.150 * * * \\
(0.033)\end{array}$ \\
\hline Unemployed & $\begin{array}{l}-0.131 \\
(0.082)\end{array}$ & $\begin{array}{l}-0.139 \\
(0.087)\end{array}$ & $\begin{array}{l}-0.139 \\
(0.087)\end{array}$ & $\begin{array}{l}-0.171^{*} \\
(0.089)\end{array}$ & $\begin{array}{l}-0.166^{*} \\
(0.100)\end{array}$ & $\begin{array}{l}-0.163 \\
(0.100)\end{array}$ \\
\hline Not in Labour Force & $\begin{array}{c}0.007 \\
(0.053)\end{array}$ & $\begin{array}{c}0.003 \\
(0.055)\end{array}$ & $\begin{array}{l}0.004 \\
(0.055)\end{array}$ & $\begin{array}{c}0.061 \\
(0.058)\end{array}$ & $\begin{array}{c}0.042 \\
(0.061)\end{array}$ & $\begin{array}{c}0.045 \\
(0.061)\end{array}$ \\
\hline Parent & $\begin{array}{c}0.089 \\
(0.064)\end{array}$ & $\begin{array}{c}0.082 \\
(0.062)\end{array}$ & $\begin{array}{c}0.081 \\
(0.062)\end{array}$ & $\begin{array}{c}0.176^{* *} \\
(0.070)\end{array}$ & $\begin{array}{c}0.167^{* *} \\
(0.076)\end{array}$ & $\begin{array}{c}0.164 * * \\
(0.076)\end{array}$ \\
\hline $\begin{array}{l}\text { Household Income } \\
(10000)\end{array}$ & $\begin{array}{c}0.005 \\
(0.003)\end{array}$ & $\begin{array}{c}0.006^{* *} \\
(0.003)\end{array}$ & $\begin{array}{c}0.006^{* *} \\
(0.003)\end{array}$ & $\begin{array}{c}0.001 \\
(0.003)\end{array}$ & $\begin{array}{l}-0.003 \\
(0.003)\end{array}$ & $\begin{array}{l}-0.003 \\
(0.003)\end{array}$ \\
\hline $\begin{array}{l}\text { Hours Worked per } \\
\text { Week }\end{array}$ & $\begin{array}{l}-0.002^{*} \\
(0.001)\end{array}$ & $\begin{array}{l}-0.003^{*} \\
(0.001)\end{array}$ & $\begin{array}{l}-0.003^{*} \\
(0.001)\end{array}$ & $\begin{array}{c}0.001 \\
(0.001)\end{array}$ & $\begin{array}{c}0.001 \\
(0.001)\end{array}$ & $\begin{array}{c}0.001 \\
(0.001)\end{array}$ \\
\hline $\begin{array}{l}\text { Hours Commute per } \\
\text { Week }\end{array}$ & $\begin{array}{l}0.002 \\
(0.004)\end{array}$ & $\begin{array}{c}0.002 \\
(0.004)\end{array}$ & $\begin{array}{c}0.002 \\
(0.004)\end{array}$ & $\begin{array}{l}0.002 \\
(0.004)\end{array}$ & $\begin{array}{c}0.002 \\
(0.004)\end{array}$ & $\begin{array}{c}0.002 \\
(0.004)\end{array}$ \\
\hline $\begin{array}{l}\text { Residential Tenure } \\
\text { (Years) }\end{array}$ & & $\begin{array}{c}-0.007^{* * *} \\
(0.002)\end{array}$ & $\begin{array}{c}-0.007^{* * *} \\
(0.002)\end{array}$ & & $\begin{array}{l}0.005^{*} \\
(0.003)\end{array}$ & $\begin{array}{l}0.005^{*} \\
(0.003)\end{array}$ \\
\hline Urban & & $\begin{array}{c}0.027 \\
(0.067)\end{array}$ & $\begin{array}{c}0.035 \\
(0.064)\end{array}$ & & $\begin{array}{c}-0.277^{* * *} \\
(0.086)\end{array}$ & $\begin{array}{c}-0.303 * * * \\
(0.082)\end{array}$ \\
\hline Wave 6 & $\begin{array}{c}-0.083^{* * *} \\
(0.016)\end{array}$ & $\begin{array}{c}-0.089 * * * \\
(0.017)\end{array}$ & $\begin{array}{c}-0.085^{* * *} \\
(0.020)\end{array}$ & $\begin{array}{c}-0.070 * * * \\
(0.018)\end{array}$ & $\begin{array}{c}-0.090 * * * \\
(0.018)\end{array}$ & $\begin{array}{l}-0.039 * \\
(0.022)\end{array}$ \\
\hline Observations & 15,086 & 15,086 & 15,086 & 15,086 & 15,086 & 15,086 \\
\hline R-squared & 0.007 & 0.010 & 0.010 & 0.014 & 0.043 & 0.043 \\
\hline Number of Individuals & 7,543 & 7,543 & 7,543 & 7,543 & 7,543 & 7,543 \\
\hline Education Controls & NO & YES & YES & NO & YES & YES \\
\hline SES Controls & NO & YES & YES & NO & YES & YES \\
\hline $\begin{array}{l}\text { Dependent Variable } \\
\text { Mean }\end{array}$ & 4.9305 & 4.9305 & 4.9305 & 4.7482 & 4.7482 & 4.7482 \\
\hline
\end{tabular}

Note: Robust standard errors in parentheses. ${ }^{* * *} p<0.01,{ }^{* *} p<0.05,{ }^{*} p<0.1$ 
Table 9- Fixed effects estimates - Dependent Variable: People in this neighbourhood can be trusted
(1) Combined
(2) Stayers
(3) Movers

\begin{tabular}{llll}
\hline Panel A & & & \\
Ethnic Frac & $-0.170^{* * *}$ & $-0.173^{* *}$ & $-0.160^{* * *}$ \\
(std. err.) & $(0.038)$ & $(0.088)$ & $(0.042)$ \\
Education Controls & YES & YES & YES \\
SES Controls & YES & YES & YES \\
R squared & 0.043 & 0.022 & 0.100 \\
Sample size & 15,086 & 11,388 & 3,698 \\
Test stat & & 0.031 & -0.176 \\
\hline Panel B & & & \\
Linguistic Frac & $-0.150^{* * *}$ & 0.0007 & $-0.206^{* * *}$ \\
(std. err.) & $(0.033)$ & $(0.062)$ & $(0.039)$ \\
Education Controls & YES & YES & YES \\
SES Controls & YES & YES & YES \\
R squared & 0.043 & 0.021 & 0.107 \\
Sample size & 15,086 & 11,388 & 3,698 \\
Test stat & & -2.145 & 1.096 \\
\hline
\end{tabular}

Note: Robust standard errors in parentheses. ${ }^{* * *} p<0.01,{ }^{* *} p<0.05,{ }^{*} p<0.1$

\# $\mathrm{z}$ score for a test of difference between these coefficients and the coefficients reported in column (1)

\section{Table 10 - Fixed Effects Using Alternative Dependent Variables}

\begin{tabular}{|c|c|c|c|c|c|c|}
\hline & $\begin{array}{l}\text { Most people } \\
\text { would try to } \\
\text { take advantage } \\
\text { of you if they } \\
\text { got a chance }\end{array}$ & $\begin{array}{l}\text { Most people } \\
\text { you meet keep } \\
\text { their word }\end{array}$ & $\begin{array}{l}\text { Most people } \\
\text { you meet make } \\
\text { agreements } \\
\text { honest }\end{array}$ & $\begin{array}{l}\text { This is a close- } \\
\text { knit } \\
\text { neighbourhood }\end{array}$ & $\begin{array}{l}\text { People in this } \\
\text { neighbourhood } \\
\text { generally do not } \\
\text { get along }\end{array}$ & $\begin{array}{c}\text { People in this } \\
\text { neighbourhood } \\
\text { generally do not } \\
\text { share the same } \\
\text { values }\end{array}$ \\
\hline \multicolumn{7}{|l|}{ Panel A } \\
\hline Ethnic Frac & -0.033 & -0.026 & -0.030 & -0.283 & 0.100 & 0.129 \\
\hline (std. err.) & $(0.040)$ & $(0.034)$ & $(0.031)$ & $(0.041)^{* * *}$ & $(0.043)^{* *}$ & $(0.042)^{* * *}$ \\
\hline$\%$ stand. dev. & $1.9 \%$ & $1.9 \%$ & $2.4 \%$ & $19.23 \%$ & $7.04 \%$ & $9.1 \%$ \\
\hline \multicolumn{7}{|l|}{ Panel B } \\
\hline Linguistic Frac & -0.027 & 0.002 & -0.035 & -0.248 & 0.064 & 0.097 \\
\hline (std. err.) & (0.033) & $(0.031)$ & $(0.027)$ & $(0.033)^{* * *}$ & $(0.036)^{*}$ & $(0.036)^{* * *}$ \\
\hline$\%$ stand. dev. & $1.6 \%$ & $0.15 \%$ & $2.8 \%$ & $16.85 \%$ & $4.5 \%$ & $6.9 \%$ \\
\hline
\end{tabular}

Note: Possible answers range from 1 to 7 , where 1 corresponds to "strongly disagree" and 7 corresponds to "strongly agree".

Robust standard errors in parentheses. ${ }^{* * *} p<0.01,{ }^{* *} p<0.05, * p<0.1$ 
Table 11 - Sensitivity test - Effect of fractionalisation on trust by migrant status

\begin{tabular}{lll|ll}
\hline & \multicolumn{2}{c}{ No Migrants } & \multicolumn{2}{c}{ Only Migrants } \\
\hline & Generalized trust & Local Trust & Generalized trust & Local Trust \\
Ethnic Frac & -0.013 & -0.183 & 0.019 & -0.125 \\
(std. err.) & $(0.035)$ & $(0.042)^{* * *}$ & $(0.090)$ & $(0.088)$ \\
Education Controls & YES & YES & YES & YES \\
SES Controls & YES & YES & YES & YES \\
Sample size & 11,998 & 11,998 & 3,088 & 3,088 \\
\hline & \multicolumn{2}{c}{ No Migrants } & & \multicolumn{2}{c}{ Only Migrants } \\
& Generalized trust & Local Trust & Generalized trust & Local Trust \\
Linguistic Frac. & -0.025 & -0.200 & 0.019 & 0.015 \\
(std. err.) & $(0.030)$ & $(0.037)^{* * *}$ & $(0.066)$ & $(0.074)$ \\
Education Controls & YES & YES & YES & YES \\
SES Controls & YES & YES & YES & YES \\
Sample size & 11,998 & 11,998 & 3,088 & 3,088 \\
\hline
\end{tabular}

Note: Robust standard errors in parentheses. ${ }^{* * *} p<0.01,{ }^{* *} p<0.05,{ }^{*} p<0.1$ 